\title{
Jidor Sentulan: Kajian Rekonstruksi dan Budaya
}

\author{
Koko Hari Pramono ${ }^{a, 1}$, \\ a Sekolah Tinggi Kesenian Wilwatikta, Jalan Klampis Anom II, Surabaya, Indonesia, 60117 \\ ${ }^{1}$ kokosakeizme@gmail.com*
}

\begin{tabular}{ll}
\hline INFO ARTIKEL & ABSTRAK \\
\hline Sejarah Artikel: & Jidor Sentulan merupakan kesenian tradisional asli Jombang yang \\
Diterima: 26-09-2019 & keberadaannya terancam di era modernisasi saat ini. Penelitian ini \\
Direvisi: 11-11-2019 & bertujuan melakukan rekonstruksi kesejarahan dan kandungan nilai \\
Disetujui: 18-11-2019 & $\begin{array}{l}\text { budaya yang terdapat dalam pertunjukan Jidor Sentulan. Penelitian } \\
\text { dilakukan di desa Bongkot, Kecamatan Peterongan, Kabupaten Jombang. }\end{array}$ \\
\hline Kata Kunci: & Jenis penelitian yang digunakan adalah deskriptif kualitatif. Sumber data \\
jidor sentulan & penelitian adalah pertunjukan dan informan. Hasil penelitian \\
nilai budaya & menunjukkan bahwa kesenian ini muncul pada kisaran 1830-1840 di \\
rekonstruksi & bawa oleh seorang prajurit Pangeran Diponegoro. Pertunjukan ini \\
& berbentuk drama yang mementaskan sebuah lakon dalam pertunjukannya. \\
& Cerita yang dipentaskan dalam pertunjukan memiliki nilai budaya, yaitu \\
& mengenai hakikat hidup manusia, hakikat karya manusia, dan hakikat \\
& hubungan antarmanusia.
\end{tabular}

\begin{tabular}{ll}
\hline ABSTRACT \\
\hline Keywords: & Jidor Sentulan is a folk art of Jombang whose existence is threatened in the \\
jidor Sentulan & current era of modernization. The aim of this study is to reconstruct the \\
cultural value & historical and cultural content contained in the Jidor Sentulan show. The \\
reconstruction & study was conducted in the village of Bongkot, District of Peterongan, \\
& Jombang Regency. This type of research is descriptive qualitative. \\
& Research data sources are performances and informants. The results \\
& showed that this art appeared in the range $1830-1840$ brought by a soldier \\
& Prince Diponegoro. This performance takes the form of a drama that plays \\
& a play in the show. The story that is staged in the show has cultural value, \\
& which is about the nature of human life, the nature of human work, and the \\
& nature of human relations.
\end{tabular}

(C) Cultural Institute, University of Muhammadiyah Malang, Indonesia

\section{PENDAHULUAN}

Kesenian daerah sebagai salah satu bagaian kebudayaan Nasional masih perlu dibina dan dikembangkan untuk keperluan pembentukan kebudayaan Nasional. Kesenian mempunyai arti penting dalam kehidupan manusia karena dapat memberikan berbagai manfaat antara lain: sebagai hiburan dan sarana komunikasi juga sebagai sarana ekspresi komunikasi seorang seniman kepada orang lain, baik kepada penonton atau penikmat.

Kesenian pada dasarnya adalah salah satu cara seseorang memasyarakat.
Kesenian adalah ekspresi seseorang untuk berhubungan dengan orang lain. Perkara ini amat menggejala dalam seni pertunjukan, sebab ekspresi seseorang dalam seni pertunjukan memerlukan orang lain dalam aktivitasnya. Mungkinkah seni pertunjukan tanpa kehadiran orang lain sebagai penontonnya? Memang, dalam kesenian masyarakat sederhana di masa lampau, seperti tarian atau perilaku teatrikal sering dilakukan tanpa adanya penonton seperti yang dikisahkan oleh sarjana Sarasin ditengah belantara ketika menyaksikan secara sembunyi-sembunyi sejumlah lelaki 
Wedoide Srilangka mengadakan upacara tarian berburu (curt sach). Namun itu juga dilakukan dalam hubungan pengertian komunikasi suku terhadap arwah-arwah nenek moyang.

Pada dasarnya penonton tarian atau laku dramatik seperti itu tetap ada, yakni roh-roh nenek moyang mereka yang dianggap hadir dalam upacara tarian berburu itu, sisa-sisa upacara tarian seperti itu masih banyak terdapat di Indonesia, misalnya bagaimana penari atau aktor membelakangi penontonya selama pertunjukan atau setidak-tidaknya kurang peduli dimana penonton berada. Ini disebabkan lantaran seni pertunjukan mereka memang bukan untuk ditonton sesama manusia, tetapi oleh para dewa atau para hyang. Jadi pada dasarnya sebuah tarian atau laku dramatik adalah bahasa komunikatif, untuk pihak yang lain.(Sumardjo, 2004).

Dalam era sekarang usaha pembangunan dan moderenisasi telah memberikan tantangan berupa ancaman terhadap kesenian dan kebudayaan rakyat (Andalas, 2018). Peristiwa-peristiwa diskusi yang dilakukan oleh kantong-kantong kebudayaan mencoba untuk menghadapi perubahan sosial yang cepat dalam menghadapi pengaruh kebudayaan dari luar akibat moderenisasi. Keberadaan kesenian daerah mulai terpinggirkan dan ditinggalkan oleh generasi muda. Hal ini disebabkan karena kurangnya pelestarian kesenian rakyat dan minimnya penelitian yang mengkaji kesenian daerah (Santosa, 2008).

Salah satu kesenian tradisional yang masih bertahan hingga saat ini adalah Jidor Sentulan. Jidor Sentulan merupakan pertunjukan drama rakyat yang mengangkat kisah kehidupan manusia. Dalam setiap lakon pertunjukannya biasanya menyelipkan mengenai petuah-petuah kepada penontonya. Pesan-pesan ini berkaitan dengan cara-cara manusia dalam menjalani kehidupannya di dunia ini.

Berdasarkan hal tersebut penelitian ini bertujuan untuk merekonstruksi sejarah keberadaan Jidor Sentulan yang ada desa
Bongkot Kecamatan Peterongan Kabupaten Jombang dan nilai-nilai budaya yang terkandung di dalamnya.

\section{METODE}

Penelitian ini merupakan penelitian deskriptif kualitatif karena bertujuan mendeskripsikan temuan penelitian menggunakan data verbal bukan angkaangka (Aminudin, 1990; Arikunto, 1997: Sugiyono, 2008). Sumber data penelitian adalah pertunjukan Jidor Sentulan dan informan penelitian. Penelitian dilakukan langsung di desa Bongkot oleh peneliti. Teknik pengumpulan data yang digunakan dalam penelitian adalah teknik perekaman dan wawancara. Setelah data diperoleh dilakukan transkripsi dan transliterasi untuk kemudian dianalisis.

\section{HASIL DAN PEMBAHASAN}

Berdasarkan penelitian yang dilakukan, berikut dipaparkan mengenai hasil dan pembahasan penelitian terkait tujuan penelitian, yaitu rekonstruksi kesenian dan nilai budaya yang terkandung di dalamnya.

\section{Kesenian Jidor Sentulan di Desa Bogot}

Keberadaan kesenian Jidor Sentulan di desa Bogot memiliki sejarah perkembangan yang cukup panjang. Berikut dipaparkan mengenai kondisi geografis desa Bogot dan asal-usul kesenian Jidor Sentulan di desa Bogot Kabupaten Jombang.

\section{Gambaran Umum Desa Bongkot Kecamatan Peterongan Kabupaten Jombang}

Berdasarkan data letak geografis Desa Bongkot Kecamatan Peterongan kabupaten jombang, termasuk dataran rendah, Desa Bongkot berjarak $4 \mathrm{Km}$ dari Kecamatan Peterongan, $10 \mathrm{Km}$ dari Kabupaten Jombang. Di Desa Bongkot terdapat Dusun Sentulan.

Desa Bongkot mengalami kemajuan seiring dengan perkembangan jaman. Dulu Desa Bongkot masih minim penduduk namun kependidikan di Desa mengalami kemajuan karena banyak pemuda Desa yang 
belajar diluar Kota. Masyarakat Desa Bongkot sebagaian besar bermata pencaharian petani dan swasta namun ada sebagaian Desa Bongkot kecil sekarang ini yang bekerja sebagai guru atau pegawai negeri lainya.

Kondisi Desa Bongkot boleh dikatakan sebagai wilayah pedesaan yang masih alami karena sebagaian besar penduduk Desa Bongkot bertani, sehingga masyarakat mempunyai banyak waktu untuk menikmati dan sebagaian ada yang mempelajari kesenian yang terdapat di desa Bongkot tersebut.

Pada kesenian Jidor Sentulan yang ada di Desa Bongkot, banyak disukai oleh masyarakat, terbukti apabila ada kesenian ini dipentaskan, masyarakat berbondongbondong baik itu masyarakat dari Desa Bongkot maupun dari tetangga desa untuk melihatnya.

\section{Asal-Usul Kesenian Jidor Sentulan}

Asal-usul kesenian tradisional "Jidor Sentulan" pertama kali muncul pada kisaran tahun 1830-1840. Konon, kesenian ini dibawa oleh salah seorang prajurit Pangeran Diponegoro di mana pada masa 1830 Perang Diponegoro telah berhasil dipadamkan oleh Kompeni. Terbilang banyak prajurit Diponegoro yang tercerai salah satu atau beberapa dari prajurit Diponegoro tersebut sempat tinggal atau menetap di Dusun Sentulan atau Desa Bongkot, di mana jenis kesenian ini tumbuh di sini. Dan, seiring bergulirnya waktu, kesenian ini terus bergerak dan sangat digandrungi masyarakat di sekitarnya.

Menurut data yang diperoleh Keunikan kesenian Jidor Sentulan adalah pada penampilan prosesinya. Terdapat juga upacara ritual yang merupakan perpaduan antara Islam dan Dinamisme, karena pertunjukan ini dibalut oleh yang mengusung irama terbang jidor dan dibarengi dengan lantunan suara yang mendengungkan nada shalawat seperti Sholatullah salamulloh/ Ala toha rosulillah/ Sholatulloh salamulloh/ Ala yasin habibillah....
Pertunjukan ini juga dihiasi dengan aroma wangi kemenyan, yang merupakan ritus transisi dari zaman kepercayaan agama Islam. Kesenian ini merupakan sebuah cermin dalam upaya melihat perkembangan Islamisasi.

Menurut data yang diperoleh peneliti mulai generasi ke pertama sampai generasi ke tiga, Jidor Sentulan merupakan hadiah kepada mempelai yang akan menikah dan hendak masuk Islam. Selain itu, masyarakat juga menggelar kesenian ini untuk memeriahkan acara khitanan.

Jidor Sentulan memiliki keunikan dan cirikhas kesenian lainnya, karena dalam kesenian ini terdapat drama rakyat yang tidak mempunyai judul cerita. Peraga utama di Jidor Sentulan adalah "Jepaplok" yang digambarkan dalam bentuk harimau kumbang dengan pencitraan yang dikenal dengan sebutan "Kumbang Semendung".

Seiring dengan berjalanya waktu, kesenian Jidor Sentulan berkembang mulai adanya tujuan dan fungsi. Tujuan dan fungsi tersebut antara lain dengan acara ritual dan hiburan (Antoni, 2009). Sebagai masyarakat agraris, masyarakat desa Mbongkot memiliki tradisi ritual seperti ruwatan desa, untuk membersihkan desa agar masyarakat yang tinggal di desa tersebut selamat dan banyak rezekinya karena begitulah kepercayaan masyarakat sekitar Desa.

Selain difungsikan sebagai ritual, saat ini kesenian Jidor Sentulan dapat di fungsikan sebagi hiburan yakni digunakan sebagi acara perlombaan 17 Agustus; perlombaan antar Kecamatan, khitanan dan sebagainya. Pada jaman dahulu kesenian Jidor Sentulan digunakan sebagai persembahan pernikahan oleh mempelai laki-laki kepada mempelai perempuan dalam rangka Islamisasi.

Adanya kesenian Jidor Sentulan di Desa Bongkot Kecamatan Peterongan Kabupaten Jombang tidak terlepas dari tokoh-tokoh seniman yang tetap menjaga dan melestarikannya, tokoh ini ada hanya sebagai ketua kelompok. Artinya yang memegang peranan dalam kesenian Jidor Sentulan / yang memiliki kesamaan. Proses 
kepemimpinan ini dulunya terjadi secara turun-temurun.

Saat ini kesenian Jidor Sentulan di Desa Bongkot Kecamatan Peterongan Kabupaten Jombang dipimpin oleh Kepala Dusun Sukar dan kelompok kesenian ini bernama Sanggar Condro Boyo. Pak Sukar memegang peranan sebagai ketua karena di anggap sebagai tokoh pemimpin di dusun tersebut. Tapi kesenian ini disecara turuntemurun dari generasi ke generasi yang diwarisi oleh generasi sebelumnya. Proses ini dapat dilihat pada skema.

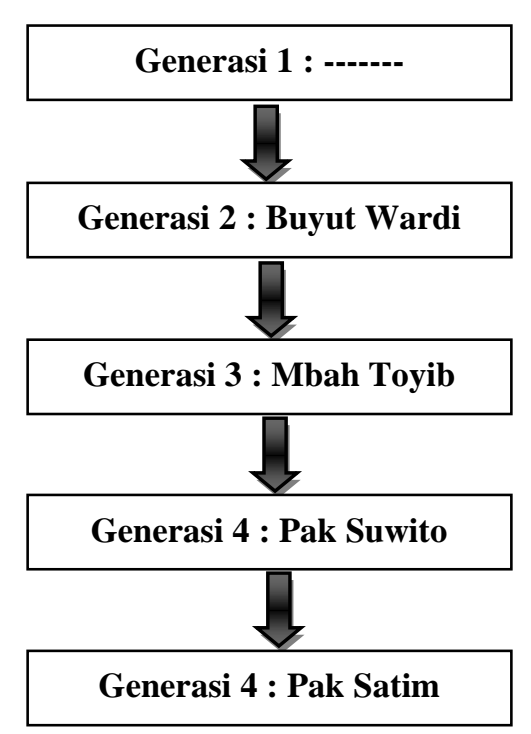

Gambar 1. Pewaris Jidor Sentulan

Berdasarkan uraian dan penjelasan tersebut dapat dianalisis bahwa asal-usul kesenian Jidor Sentulan di Desa Bongkot didasarkan atas cerita pada masa animisme menuju dinamisme.

Dari generasi pertama samapi generasi ke tiga Mbah Toyib, masyarakat melakukan kesenian Jidor Sentulan berfungsi sebagai persembahan pernikahan oleh mempelai laki-laki kepada mempelai perempuan dalam rangka Islamisasi karena pada waktu itu kesenian rakyat merupakan alat yang ampuh untuk mengumpulkan masa dan digunakan sebagai media dakwah.

Pada generasi ke empat dan kelima yaitu Pak Satim dan Pak Suwito kesenian Jidor Sentulan digunakan ritual ruwatan Desa, kemudian berhubung kesenian ini tidak hanya sebagai ritul semata tetapi juga telah menjadi hiburan masyarakat. Proses pewarisan terjadi karena turun-temurun.

\section{Lagu Pada Jidor Sentulan}

Sejak awal kemunculanya dari generasi pertama sampai generasi terakhir, pertunjukan kesenian Jidor Sentulan dibalut oleh musik yang mengusung irama Terbang Jidor dan dibarengi dengan lantunan suara yang mendengungkan nada shalawat tapi pelantunanya seperti irama pelantunan Parikan, menurut analisis yang dilakukan penulis gaya parikkan pada pelantunan lagu shalawat dikarenakan secara geografis kesenian ini muncul di kota Jombang dimana paarikan itu berasal. Berikut ini adalah lirik lagu shalawat yang terdapat pada kesenian Jidor Sentulan:

\section{Sholatullah salamulloh \\ Ala toha rosulillah \\ Sholatulloh salamulloh \\ Ala yasin habibillah}

Penerjemahan $\mathrm{k}$ edalam bahasa Indonesia yang dilakukan oleh peneliti sebagai berikut:

\section{Rahmat Allah dan keselamatan Allah Semoga diberikan kepada beliau Nabi Muhammad \\ Rahmat Allah dan keselamatan Allah Yang menjadi kekasih allah}

\section{Nilai Budaya Pada Kesenian Jidor Sentulan}

Suatu sistem nilai budaya terdiri dari konsepsi-konsepsi yang hidup dalam alam pikir masyarakat pemiliknya (Koentjaraningrat, 2000; Andalas, 2015, 2016, 2017). Karena itu warga masyarakat Desa Bongkot menganggap bahwasannya suatu sistem nilai budaya biasanya berfungsi sebagai pedoman tertinggi dari kelakuan manusia. Sistem nilai budaya mengenai tata 
kelakuan manusia bisa di ilhami dari kesenian Jidor Sentulan yang syarat akan bentuk-bentuk nilai budaya manusia dalam pementasannya.

\section{Hakikat Hidup Manusia}

Kebudayaan yang memandang hidup manusia itu suatu hal yang buruk dan menyedihkan, dan karena itu harus dihindari. Sebelum masuknya agama Islam di Desa Bongkot yang dibawa oleh salah seorang prajurit Pangeran Diponogoro yang menggunakan media dakwah berupa kesenian Jidor Sentulan dahulu pada masa generasi pertama yang tidak dapat dilacak keberadaannya, masyarakat Desa Bongkot masih terpengaruh oleh kebudayaan agama Budha misalnya dapat disangka mengkonsepsikan hidup sebagai suatu hal yang buruk. Pola-pola kelakuan manusia pada masa itu akan mementingkan segala usaha untuk menuju kearah tujuan untuk bisa memadamkan hidup itu, dan meremehkan segala kelakuan yang hanya mengekalkan rangkaian kelahiran kembali. Tetapi sejak Islamisasi desa Bongkot melalui kesenian Jidor Sentulan yang dibawa oleh prajurit Pangeran Diponogoro, warga masyarakat mulai memiliki kebudayaan yang memandang hidup manusia itu pada hakikatnya buruk, tapi manusia dapat mengusahakan untuk menjadikan hidup menjadi suatu hal yang baik dan menggembirakan dan ini juga yang menjadikan peralihan fungsi Jidor Sentulan sekarang sebagai hiburan masyarakat.

\section{Hakikat Karya Manusia}

Dalam kesenian Jidor Sentulan di desa Bongkot, terdapat nilai budaya yaitu masalah mengenai hakikat dari karya manusia (selanjutnya disingkat $\mathrm{MK}$ ). Menurut analisis yang dilakukan peneliti, Jidor Sentulan merupakan kesenian yang digunakan sebagai alat Islamisasi masyarakat Desa Bongkot yang dibawa oleh salah seorang prajurit Pangeran Diponegoro di mana pada masa 1830 Perang Diponegoro telah berhasil dipadamkan oleh Kompeni. Terbilang banyak prajurit Diponegoro yang tercerai-berai hingga berkelana ke daerah Jawa Barat dan Jawa Timur. Ada salah satu atau beberapa dari prajurit Diponegoro tersebut sempat tinggal atau menetap di dusun Sentulan atau desa Bongkot, di mana jenis kesenian ini tumbuh di sini. Dan, seiring bergulirnya waktu, kesenian ini merupakan media untuk menyebarkan agama Islam pada waktu itu.

Hakikat karya manusia pada kesenian Jidor Sentulan merupakan hasil dari sistem nilai budaya masyarakat desa Bongkot yang memaduan antara Islam dan kepercayaan dinamisme, karena pertunjukan ini dibalut oleh unsur musik yang mengusung irama terbang jidor dan dipadukan dengan lantunan suara yang mendengungkan nada shalawat seperti Sholatullah salamulloh/ Ala toha rosulillah/ Sholatulloh salamulloh/ Ala yasin habibillah.

\section{Hakikat Hubungan Manusia}

Sistem nilai budaya mengenai hakikat hubungan dari manusia pada kesenian Jidor Sentulan digambarkan dari persahabatan antara tokoh Tembem dan Pentul, jika dianalisis melaluin jalanya cerita hubungan dari manusia bisa diungkap dari tokoh Tembem yang mencoba menolong temanya si Pentul yang sekarat akibat gigitan Kumbang semendung. Hal ini menandakan bahwa budaya tolong menolong merupakan sifat kebaikan dari manusia, hal ini juga menjadi pertanda bahwa manusia merupakan mahluk sosial yang saling membutuhkan antara sesamanya. Pengayaan referensi hakikat hubungan dari manusia juga bisa diilhami dari tokoh Mbah Wiro Guno yang mau menolong Pentul yang sedang sekarat hal ini juga menjadi bukti bahwasanya melalui budaya saling tolong menolong merupakan wujud dari hakikat hubungan dari manusia itu sendiri.

Jika dilihat perkembanganya dari generasi kegenerasi pewaris kesenian Jidor Sentulan hakikat hubungan dari manusi akan tetap ada hingga akhir jaman, tetapi kadang kala hubungan antar sesama manusia bisa renggang karena keegoisan ataupun sifat buruk dari manusia itu sendiri. Hal 
demikian bisa dihindari jika kita tetap melestarikan budaya tolong menolong antara sesama manusia.

\section{KESIMPULAN}

Berdasarkan hasil penelitian analisis dengan menggunakan Kajian Revitalisasi dan Budaya pada kesenian Jidor Sentulan di Desa Bongkot selanjutnya dapat diperoleh kesimpulan sebagai berikut. Pertama, keberadaan Jidor Sentulan di desa Bongkot melalui sejarah perkembangan yang cukup panjang. Kesenian ini ada pada kurun waktu 1830-1840. Prajurit Diponegoro yang tercerai salah satu atau beberapa dari prajurit Diponegoro tersebut sempat tinggal atau menetap di dusun Sentulan atau Desa Bongkot, dimana jenis kesenian ini tumbuh disini. Seiring bergulirnya waktu, kesenian ini terus bergerak dan sangat digandrungi masyarakat di sekitarnya. Kedua, nilai budaya yang terkandung di dalam lakonlakon pertunjukan berkaitan mengenai hakikat hidup manusia, hakikat karya manusia, dan hakikat hubungan antarmanusia.

Proses regenerasi dalam Kesenian Jidor Sentulan adalah berkaitan dengan proses pewarisan. Dalam tradisi proses pewarisan artinya generasi tua kesenian Jidor Sentulan mewariskan kesenian ini kepada generasi berikutnya. Tetapi terdapat perkembangan dari generasi ke empat Pak Satim kemudian diteruskan generasi kelima Pak Suwito semenjak peralian ke generasi merekalah Jidor Sentulan mengalami perkembangan yang dimulai dari fungsi yaitu untuk menghibur rakyat dan pemanbahan dua aktor yaitu Kera dan harimau sebaagai tokoh pembantu untuk meramaikan swasana.

\section{REFERENSI}

Aminudin. (1990). Pengembangan penelitian kualitatif. HISKI komisariat Malang.

Andalas, E. F. (2015). Mitos-Mitos Kabupaten Malang: Cara Orang Jawa dalam Menjelaskan Dunianya. Puitika, 11(2), 150-162.
Andalas, E. F. (2016). Sastra Lisan Lakon Lahire Panji dalam Pertunjukan Wayang Topeng Malangan Padepokan Mangun Dharma: Kajian Sastra Lisan Ruth H Finnegan. Universitas Airlangga.

Andalas, E. F. (2017). Dampak dan Fungsi Sosial Mitos Mbah Bajing bagi Kehidupan Spiritual Masyarakat Dusun Kecopokan Kabupaten Malang Jawa Timur. Puitika, 13(1), 20-31.

Andalas, E. F. (2018). Meninjau Kembali Identitas Budaya Jawa di Era Globalisasi. In Seminar Kebudayaan Jawa (pp. 1-12).

Antoni, A. (2009). Teater dan Kembarannya. dewan kesenian Jawa Timur diterjemahkan kedalam bahasa Indonesia oleh Max Arifin.

Arikunto, S. (1997). Prosedur Penelitian. Jakarta: Reineka Cipta.

Danandjaja, J. (2002). Folklor Indonesia. Jakarta: PT Pustaka Utama Grafiti.

Koentjaraningrat. (2000). Kebudayaan, Mentalitas dan Pembangunan. Jakarta: PT Gramedia Pustaka Utama.

Peursen, van. (1976). Strategi Kebudayaan. Jakarta : BPK Gunung Mulia.

Santosa, Eko, dkk. (2008). Seni Teater Jilid I. Jakarta: Direktorat Pembinaan Sekolah Menengah Kejuruan.

Santosa, Eko, dkk. (2008). Seni Teater Jilid II. Jakarta: Direktorat Pembinaan Sekolah Menengah Kejuruan.

Sugiyono. (2008). Metode Penelitian Pendidikan, Pendekatan Kuatitatif, Kualitatif. Bandung : CV Afabeta. 
Sumardjo, J. (2004). Perkembangan Teater Moderen dan Sastra Drama Indonesia. Jakarta: STSI PRESS. 